\title{
Documentation of Endangered Dialect of the Igbo Language: Issues of Greetings in Enugwu Ezike Dialect
}

\author{
Juliana Ginika Mamah \\ Department of Linguistics, Igbo \& Other Nigerian Languages, University of Nigeria, Nsukka, Nigeria \\ Jacinta Ukamaka Eze \\ Department of Linguistics, Igbo \& Other Nigerian Languages, University of Nigeria, Nsukka, Nigeria \\ Bestman Esegbuyiota Odeh \\ Department of Linguistics, Igbo \& Other Nigerian Languages, University of Nigeria, Nsukka, Nigeria \\ Ifeanyi John Nwosu \\ Department of Linguistics, Igbo \& Other Nigerian Languages, University of Nigeria, Nsukka, Nigeria
}

\begin{abstract}
This paper studies the documentation of endangered dialect of the Igbo language: Issues of greetings in Enugwu Ezike dialect. The objectives of the study are to identify different types of greetings in Enugwu Ezike, examine the extent to which other dialects, standard Igbo or English language are preferred in greetings in Enugwu Ezike and also to proffer measures through which the greeting patterns can be revitalised. The data for the study were gathered through introspection and unstructured oral interview. Using descriptive method of data analysis, the study discovers different types of greetings in Enugwu Ezike dialect ranging from daily greetings, greetings to the sick, farewell greetings, seasonal/ periodic greetings, eulogy/praise greetings etc. The study also discovers that many speakers of Enugwu Ezike dialect especially the younger generation prefer the greeting patterns of other dialects and languages. In order to avert this ugly phenomenon, the study suggests measures towards reviving this aspect of the dialect which are through documentation, awarenessraising through programs on radio and television stations, involving the young people via social media and the loyalty of the speakers towards their dialect. The study therefore recommends that researchers from Enugwu Ezike extraction should endeavour to work on other aspects of Enugwu Ezike dialect that is under threat of endangerment or outright extinction.
\end{abstract}

Index Terms —endangered, language, Enugwu-Ezike, Igbo, greetings

\section{INTRODUCTION}

Documentation is very important in language study. It is one of the major means to preserve and safeguard languages or dialects. Documentary linguistics as a new sub-field of linguistics is primarily concerned with providing comprehensive records of linguistic practice for which a speech community is known. It is sometimes used interchangeably with language description. However, certain nuances are discernible between the concept and language description in that the later aims at records of language as a system of abstract elements, constructions and rules (Himmelmann, 1998). Documentation is an aspect of language engineering that provides the data base for theorising in linguistics and also forms the basis for developing and producing orthography of descriptive grammar, extended word list and dictionaries (Ndimele, 2010).

A language is said to be endangered when it is at the risk of no longer being used as occasioned by the demise of its speakers or when the speakers shift to speaking another language. It becomes a dead language when it has no more native speakers. This condition is also referred to as language loss. Different levels or categories of endangerment have been identified by many scholars. Aikawa in UNESCO (2001) ranks in a continuum from stability to extinction as follows: extinct which occur when there is no one who can speak or remember the language; critically endangered where the youngest speakers are in the great grand parents' generation and the language is not used for every day interaction; severely endangered when the language is spoken by only grandparents and other generations while the parents' generation may still understand the language but they typically do not speak it to their children among themselves; definitely endangered when it is no longer learned as the mother tongue by the children in the home. The youngest speakers are thus of the parental generation.

Perhaps, Wurm's (2003) categorisation of endangerment will be more appropriate. He identifies five levels of language endangerment: (a) potentially endangered if the children starts preferring the dominant language, (b) endangered if the youngest speakers are young adults, and only very few speakers. (c) Seriously endangered if the 
youngest speakers are middle aged or past middle aged, (d) terminally endangered or moribund if there are only a few elderly speakers and (e) dead where there are no speakers left. Greeting aspect of Enugwu Ezike dialect may be said to be potentially endangered if the present circumstances of the dialect continue to degenerate in the face of the continuing English, standard Igbo and contiguous dialects dominance; or the flagrant abandonment or unwillingness of native speakers to observe the age long practice. The need for the examination of the language and dialect levels of endangerment is to properly locate the position of Enugwu Ezike dialect with respect to the greetings aspect. The rising interests in researches on language/dialect endangerment is to redirect the focus of linguists and policy makers to the area in view of the potential loss of valuable linguistic and cultural resources around the globe (Crystal, 2000, Bradley and Bradley, 2002; Mufwere, 2004). A whole lot of the studies on language endangerment in Nigeria have centered on the threats to minority languages by the dominant languages or by English language (Igboanusi and Peters, 2004). This present research, however takes a step further to investigate an aspect of Enugwu Ezike dialect (Greeting) that is under serious threat.

Generally, greetings are seen as socio-linguistic behaviour based on the culture of the people. In Igbo socio-cultural societies, the importance of greetings can hardly be overstated as it helps to establish and maintain personal relationships; and show care to anyone to whom it is expressed among others. Greetings in Enugwu Ezike have different dimensions or types. There are daily greetings, seasonal or periodic greetings, royalties/pedigree greetings, eulogy/praise greetings, greetings at place of work, etc. To guarantee a deeper understanding of Nigerian languages and dialects, culture, history and societies, the documentation of Nigeria dialects or languages underscores the relevance of the present study.

The researchers observe overtime that greetings, a vital aspect of the dialect are rarely used in the way they ought to be used by speakers of the dialect. Majority of the speakers of the dialect now opt for standard Igbo, contiguous dialects of Igbo language or English language as a means of greeting; or are unwilling to observe the age long practice of greeting in Enugwu Ezike speech community. This trend worries the researchers as it portends ominous danger to the survival of the dialect. This situation is the problem of this study. The objectives of this study are to identify different types of greetings in Enugwu Ezike., determine the extent to which other dialects, standard Igbo or English language are preferred in greetings in Enugwu Ezike dialect and proffer measures towards the revitalisation of greetings in Enugwu Ezike dialect. This study covers Enugwu Ezike speech community in Igbo Eze North Local Govt. area of Enugu State. The present study is very significant in a number of ways. Firstly, it is a clarion call to re-awaken the consciousness of speakers of Enugwu Ezike dialect on the seemingly jettisoned but important aspect of their dialect to enable them takes appropriate steps to uphold and preserve it so as to further enrich their cherished dialect. Secondly, since there is limited literature in this area of study, linguists and further researchers in this area will find the work a useful guide and lastly, it will also avail speakers of other native dialects of Igbo the opportunity of knowing the rich linguistic resources of Enugwu Ezike as exemplified in greetings.

\section{LITERATURE REVIEW}

Igboanusi (2006) carries out a study to assess the position of the Igbo language with respect to endangerment. He concluded a survey among respondents of the three major languages in Nigeria _ Hausa, Igbo and Yoruba to determine their preferred language for spoken and written domains. From the data collected, he finds out that Hausa has high preference ratings by mother tongue respondents as a spoken language (62.4 percent) and written language (51.5 percent). Igbo and Yoruba appear to have been replaced by English in both the oral and written domains. The preference rating of Igbo respondents to English was 56.5 percent for oral communication and $91.5 \%$ for communication. Yoruba respondents had 58.2 percent rating for English in oral and 88.6 percent for English in written communication. In the same vein, the same study indicates that Hausa has high preference for their mother tongue in entertainment; 70.3 percent for films and 62.9 percent for music; and average Yoruba has 44.8 percent for films and 50.7 percent for music. Surprisingly, Igbo mother tongue respondents had a low preference value for their language for entertainment; 39 percent for films and 36 percent for music. They would prefer pidgin or English language. The paper concludes that the higher preference level of the Igbo respondents for English language is an indication for their penchant for foreign ways of life which has severe effect on Igbo as a language. The study reveals a general decline in the interest in the language particularly among the younger generation. The study relates to the present one in the sense that it assesses the Igbo language endangerment but differs from the present study in the sense that it did not discuss Enugwu Ezike dialect of Igbo.

Kibe (n.d.) studies endangered language and dialects in Japan. The objectives of the study are to create a record of the endangered languages and dialects found throughout Japan, to analyse the characteristics of these languages and dialects, to consider approaches for preserving endangered languages and dialects and to support regional movements which work towards ensuring they continue as living languages. The research instrument is audio and video recordings. The study finds out that in Amamikikai dialect, first-person plural can be expressed by either 'wannah' or 'waichah'. Wannah denotes exclusionary 'we' which does not include the listener, while Waichah denotes inclusionary 'we' which does not include the listener but distinction does not exist for 'we' in standard Japanese (Watashitachi), making the Kikai dialect appear unique. The study also finds that lectures and seminars will be the means to support moments for preserving the continuation of endangered language and dialects. This study is similar with the current one as they both 
express interest in the language/dialect endangerment. However, they differ as this work attempts to examine the documentation of endangered dialect of Igbo language, issues of Enugwu Ezike dialect.

Tija (2012), in his Language endangerment and documentation: Implications for Tiv orthography, centres on the analysis of these orthographical deficiencies and inconsistencies. The study also investigates the fate of Tiv language without a unified and acceptable orthography in the face of the threats of endangerment. The study finds out that even though Tiv orthography was documented since 1911, it is very deficient and inconsistent because the missionaries that work on Tiv orthography where non-Tiv and as a result, lack adequate knowledge and understanding about Tiv sounds and graphological system. He argued that Tiv orthography lacks contemporary relevance and usage since the language has changed over the period of time and as a result makes reading and writing Tiv language difficult for scholars. Similarly, the paper also argues that different orthographies compiled by some Tiv linguists and speakers have complexities and are all at variance and controversial thereby making the language to face threat of endangerment. The study adopts the TLSDA approved version of current Tiv orthography which helps in keeping Tiv language alive. The study however, recommends that Tiv language demand serious documentation of its grammar, its lexicon, oral traditions and publication of literature texts in Tiv vernacular. It also believes that to standardize and preserve Tiv language, conferences and workshops should be organised regularly to teach and familiarise the approved Tiv orthography to the native speakers. The study further recommends that Tiv language studies and development, and all others interested in the Tiv language should use the approved TLSDA, the new orthography for their publication. This study and the present study are related as both study endangerment and documentation. It differs from the present study in the sense that it dwells on Tiv orthography.

Olaoye (2014) studies sociolinguistic documentation of endangered ethnography of communication in the Yoruba language. The study analyses and interprets the sociolinguistic structure of endangered ethnography of communication or greetings in Yoruba language using three dialects of Yoruba language: Igbomina, ijebu and Ijesa to compare with the standard Yoruba language. The study finds out that the grammatical patterns of greetings are different, particularly the difference in the plural markers and the pronouns. The study categorises greetings into time of the day-morning, afternoon, evening and night. Different types of greetings were identified such as greetings for special festival, loss of property, greetings for kings and chiefs and greetings at work. The paper continues to argue that all these forms of greetings are disappearing in the ethnography of communication of the Yoruba more especially the educated ones. The study recommends that these greetings should be documented to save them from being endangered. The work is similar to the current work in studying the documentation of endangered greetings. However, the current work centres on a dialect of Igbo.

Ayenbi (2014) studies language regression in Nigeria using the Ishekiri minority language in Delta State of Nigeria as a case study. The study examines the linguistic situation of speech communities that do not speak and use their language. Attitudes towards their own language, the chances of survival and preservation were also analysed. The study also proffers solution to revitalize and maintain the language. The study finds out that Ishekiri language might be severely endangered if adequate measure is not taken. The study therefore highlights some measures to maintain and safeguard endangered language following the suggestions of Expert in UNESCO meeting such as provision of basic linguistic and pedagogical training, providing language teachers with training in basic linguistics, language teaching method techniques; curriculum development and teaching material development, sustainable development in literacy and local documentation skills; training local workers to develop orthographies and to read, write and analyse their own languages and produce pedagogical materials. The paper also suggests that local research centres, where speakers of endangered languages will be trained to study, document and archive their own language materials should be established. The study is similar to the present study in the sense that both study language endangerment but differs from the present study in the sense that the former is case study of Ishikiri language while the later is on aspect of Enugwu Ezike dialect of Igbo language.

Obadan (2015) in her study of language endangerment: Issues of Igbo proverbs highlights, a generational gap in the use and interpretation of proverbs by the younger generation using Ogwashi-uku community in Delta State. Data for study were gathered from communal meetings of two separate groups: youth and the elders. Using the linguistic vitality and endangerment (LVE) as its framework, the study examines the competence level in the use of proverbs between the older generation of the Igbo speakers and the younger generation. The study finds out that most youth speakers lack competence in the use and interpretation of proverbs. The study is related with the present study because both centre on language endangerment. The study differs from the present one because the present study is on greetings while the later is on proverbs.

Nwankwere, Mmadike and Eme (2017) examine the possibility of Igbo parents in creating an enabling environment for acquiring/learning Igbo language within the family and the immediate locality. Employing the language maintenance perspective, data for the study were gathered through observation and interactions with thirty consultants consisting of parents residing in the north, west and south-south Nigeria, Ghana, Benin Republic, England and America. The study shows that Diaspora parents can lead their children not only to understand but to speak Igbo and therefore recommend that the Igbo language awareness and maintenance efforts should be the concern of all the Igbo, especially parents. This according to the study will ensure that wherever they live, they should acquire/learn Igbo to save the language from being endangered or going into extinction. This study is similar to the current study as both study 
language endangerment but differ as the present study deals with aspect of a dialect of Igbo language while the later is on Igbo language in general.

From the discussion, it is observed that works abound in language endangerment but dialectal endangerment has not received proper attention. Moreover, to the best knowledge of the researchers, no known work has been done on documentation of endangered aspect of Enugwu Ezike dialect: issues of greetings. This gap is the justification of this present study.

\section{METHODOLOGY}

A qualitative descriptive design was adopted for this study. The study was conducted in Enugwu Ezike, a town in Igbo Eze North Local Government Area of Enugu State. The town has an estimated population of 259,431 persons at the 2006 census. It is bounded in the north by Olamaboro Local Government Area of Kogi State; in the east by Ogbadigbo L.G.A of Benue State, in the south by Udenu L.G.A; in the south by Igbo Eze South L.G.A of Enugu State and in the west by Igalamela/Odolu L.G.A of Kogi State. This population was divided into clusters and the wards in the local government were used to represent these clusters. Then, the selective sampling to select two persons from each ward comprising male and female. The method for data collection was introspection and unstructured oral interview. The data collected were identified, transcribed, classified and analysed descriptively using the set objectives.

\section{DATA PRESENTATION AND ANALYSiS}

In this section, we present the data collected and analyse them adequately.

\section{A. Types of Greetings}

There are different types of greetings in Enugwu Ezike:

(1) Daily greetings such as:

(i) Ụnụ abọọ?- Good morning

(ii) Ụnụ ariọkwutego ishi eka nta? -Have you woken up?

(iii) Oha nta eme agaa? - How is today?

(2) Seasonal/periodic greeting example:

(i) Odobo Ishanyi shanyi - Greetings to Akatakpa Masquerade during onwa esa.

(ii) Ugwuoke Odobo -Greeting to Akatakpa Masquerade during ọwa esa festival.

(iii) Gbom ajeka -Greeting during men initiates during Omabe festival.

(iv) Mama Ndegbe - Greeting during Ndegbe moonlight masquerade between men.

(3) Greeting at place of work such as:

(i) Aanya orụ - well done work

(ii) Aanya akanya -well done work (effort)

(iii) Ike aturu -You have done well

(iv) Aanya amashi amashi -Thank you very much

(4) Royalty greetings/Pedigree Greetings

(i) Olụo ọha- Greetings to the priests of deities

(ii) Ogbuleja - Greetings to someone who has killed cow for festivities at a very tender age

(iii) Ojieshu-Greetings to a woman who buried her father or mother in-law with a cow

(iv) Ogbuzuru -To someone who has killed cow to all groups/stakeholders in the community

(v) Ude-Greetings to the eldest man in the community

(5)Eulogy/Praise Greetings

(i) Obụ eeke -Eulogy to show comradeship or companion

(ii) Ogerewu -Admiration greeting of a young girl or boy

(iii) Okanagba nyanwu nyanwu- Greetings for a big task achieved

(iv) Eeke shire shire- Greeting of a man for achieving no mean feat

(v) Onụehe atta - Greetings to a married man who creditably performs his matrimonial responsibility

(vi) Orukpo atta-Greetings to a full fledge woman who performs her matrimonial duties well

(vii) Jikpa atta -Greetings of praise to a man for doing a challenging task

(viii) Okomanyi koko -Eulogy somewhat cyclical for an action

(ix) Onyeke gadagba- Greeting to a giant man or for extra ordinary performance

(x) Oonye atukwu -Also a form of greeting to a woman for doing what is expected of a woman of her status

(6) Farewell Greetings to visitors

(i) Ladoore -bye bye

(ii) Dare ọọdụ- thanks for coming

(iii) Ahinya/maje ọnọwuru -thanks for staying

(7) Greetings to the sick and bereaved

(i) Idiọyi ekre ekre _ are you okay at all? 
(ii) onwụ ga-natụ_ it is a pity.

(iii) Gbagaa ọnwụ_ accept my condolence.

(8) Welcome Greetings

(i) Ala _ welcome

(9) Childbirth Greetings

(i) Dare omụgo _ well done for giving birth.

(ii) Omụgọ atưru _ sorry for the pain of child birth.

(iii) Aanya omugọ _ thank you for giving birth.

(iv) Orụ Nwa atưrụ_ _ well done for taking care of the child.

\section{B. The Extent to Which Other Dialects, Standard Igbo or English language Are Preferred in Greetings in Enugwu Ezike}

In daily greetings, many Enugwu Ezike native speakers prefer to use "good morning" option to 1 (i-iii) of the dialect version for morning greetings. In seasonal greetings, there are no English, standard Igbo or contiguous dialect equivalents of the greetings in example 2 (i-iv). However, the younger generations hardly use them when the need arises. The situation here is abandonment or unwillingness to use them, thereby potentially endangering the resilience of the greetings which is peculiar to native speakers of the dialect.

Also in the third type of greetings, the younger generations hardly use any of the examples in 3(i-iv) instead, they use English options or they resort to contiguous dialects "idi ike oru (Nsukka/Ideke version) or deje oru" (Nsukka version). In royalty/pedigree greetings, the younger generation prefer to substitute the dialect version to English version such as good morning, good afternoon, well done or any other one than Enugwu Ezike dialect.

In the greetings of eulogy, speakers of the dialect in recent times hardly refer to the dialect option $5(\mathrm{i}-\mathrm{x})$ rather, what is common among them are "okorobia, nwokeike, agbogho, nukwu nwanyi, 'big boy/girl', nwanyi oma nnaa" etc. Dialect version of fare well greetings to visitors such as "ladore, dare onodi and ahinya onokwuru" are usually replace with either the English language option of 'bye', thanks for coming and thanks for staying respectively or Nsukka/Ibagwa version of "ladome,idi ike onodu or deje onodu". Similarly, in greetings to the sick or bereaved; idioyi hehe(Nsukka variant) replaces "idioyi ekre ekre" while "onwu ga-atu" and "gbaga onwu" are replaced with "ndo or sorry" (standard Igbo or English language)respectively.

Another instance is in welcome greetings, while 'ala' may be used commonly as a form of welcome greeting in Enugwu Ezike dialect and Nsukka dialect, I ga-adi ike ije is peculiar to Nsukka Ideke dialect. But an average young native speaker will now prefer "I ga-adi ike ije,nno or welcome respectively. In childbirth greetings, Enugwu Ezike version of "aanya omugo, oru nwa aturu and daare Ọụgọ" are usually replaced with Nsukka or English variant "deje omugo or congratulations".

\section{Measures towards the Revitalisation of Greetings in Enugwu Ezike Dialect}

Language or dialect revitalisation is the movement to reverse the possible death of nearly extinct or endangered language or dialect. It is also referred to as language revival or reversing language shift which is an attempt to halt or reverse the decline of a language or dialect. If a community has a unique language or unique ways of greetings but perhaps only the elderly or isolated speak or use it, then no new generation of speakers are being produced, such unique pattern is on a path to extinction.

In order to avert this situation in the greeting pattern of Enugwu Ezike dialect, some measures towards the revitalisation of greetings in the speech community has to come into play.

(i) Speakers' loyalty: The speakers of Enugwu Ezike dialect must be loyal to the greeting pattern of their speech community. This is because loyalty within the community requires that the local speech form be maintained by community members. To abandon the local speech form is an act of linguistic disloyalty. The goal of the speakers should be on how to preserve their unique way which often involves the recognition and continuation of their unique ways of speaking. Speakers should value the speech pattern of their dialect because their dialect is their most communicative resource which an individual can most comfortably and effectively communicate with those who share common speech forms and norms. The speakers' knowledge of conservative dialect links the speakers to the past both at symbolic and practical level and also allows them to access and understand recorded stories and oral traditions. Loyalty and mutual use of particular greeting patterns allows the speakers to show that they share similarities and that they belong to the same group. It is also a display of one's separateness among outsides and for identity and political recognition.

(ii) Get the young people interested: The young people from Enugwu Ezike should be encouraged to use the greeting pattern of the speech community in their daily activities. This is because it is the identity marker for all Enugwu Ezike speakers. This is done by transmission from parents to children in the homes, through Enugwu Ezike music, radio programs, TV programs, websites and books etc.

(iii) Awareness-raising activities: There is need for awareness rising within and outside the speech community. This can be done with weekly programs on local radio and television stations by the speakers. In doing this, the younger and even older speakers will develop interest in using this unique pattern of their dialect. This will clearly stress local 
identity of the greeting pattern of the dialect thereby making it to be seen as a commercial asset. This will endear the dialect to Enugwu Ezike speakers.

(iv) Documentation: One way to revitalization of greeting pattern of Enugwu Ezike dialect is through conscious language engineering activities such as keeping it in retrieval or archival system like video tape, audio tape, texts etc.

\section{SUMMARY OF THE FINDINGS AND CONCLUSION}

\section{A. Summary of the Findings}

The research has successfully investigated documentation of endangered dialect of Igbo language: issues of Enugwu Ezike greetings using descriptive analysis of data. From the analysis of data, the research work was able to provide answers to the set objectives. The study while identifying the different types of greetings, observes that greetings in Enugwu Ezike dialect has so many types ranging from daily greetings, eulogy, pedigree, farewell greetings etc and that these types of greetings have different ways through which they are presented. The study also discovers that speakers of Enugwu Ezike dialect prefer to use other types of greetings from other dialects, standard Igbo and even English language thereby endangering the greeting patterns of their dialect. For instance, when they suppose to use 'ala' they prefer to say 'I ga adi ike ije' or 'welcome'; 'aanya oru' will be 'deeje oru' or well done. The study also proffers different measures towards the revitalization of this aspect of Enugwu Ezike dialect that is endangered. These measures are as follows: documentation of the greetings types and patterns, creating awareness via programs on radio and television stations, getting the younger generation interested in the patterns of greetings peculiar to Enugwu Ezike and finally speakers of Enugwu Ezike dialect must be loyal to their dialect thereby making sure that no part of the dialect is endangered.

\section{B. Conclusion}

The study has been able to answer certain questions pertaining to the greeting patterns of Enugwu Ezike dialect. The study did its best in bringing out different types of greetings in Enugwu Ezike that are threatened. It equally examined speakers' preference of other greeting patterns from other dialects and languages and different measures to revitalise it. More especially, it has added its own voice to the arguments concerning the documentation of endangered dialect of Igbo language. This study therefore, recommends that further studies be carried out on greetings of other dialects of Igbo language that is under threat.

\section{REFERENCES}

[1] Aikawa, N. (2001). UNESCO's program on languages. Conference Handbook on endangered languages of the pacific Rim 1324. Osaka: Endangered languages of the pacific Rim Project.

[2] Ayenbi, O. F. (2014). Language regression in Nigeria: The case study of Ishekiri. Department of language teaching and applied linguistics, University of Strasbourg.

[3] Bradley, D. \& Bradley, M. (2002).Language endangerment and language maintenance. London: Routledge Curzon.

[4] Crystal, D. (2000). Language death. Cambridge: Cambridge University Press.

[5] Himmelmann, N. P. (1998). Documentary and descriptive linguistics. Linguistic journal. 36:161-195

[6] Igboanusi, H. (2006). Is Igbo an endangered language? Multilingual-journal of cross-cultural and inter language communication. 25(4), 443-452.

[7] Igboanusi, H. \& Peter, L. (2004). Oppressing the oppressed: The threat of Houses and English to Nigeria's minority languages. International Journal of Sociology of Language 170, 131 - 140.

[8] Kibe, N. (n. d.). Endangered languages and dialects in Japan. National institute for Japanese language and linguistics.

[9] Mufwere, S. (2004). Language birth and death. Annual review of anthropology 33, 201-222.

[10] Ndimele, O.M. (2010). Language documentation and growing grammars for dummies. In O.M. Ndimele (Ed.) Language policy and management in Nigeria: A festschrift for Ben O. Elugbe. Port Harcourt: M\&J Grand Communications LTD.

[11] Nwankwere, A.U.N., Mmadike, B.I. \& Eme,C.A. (2017). Safeguarding the Igbo language through teaching Igbo children in Diaspora. Ogirisi: a new journal of African studies. 13(i) 1-9.

[12] Obadan, M. (2015). Language endangerment: Issues of Igbo proverbs. English linguistic research. 4(3), 1 - 12.

[13] Olaoye, A.A. (2014). Sociolinguistic documentation of endangered ethnography of communication in Yoruba language. htt://kikigengo.ninjal.ac.jp/.

[14] Tija, T. (2012). Language endangerment and documentation: Implications for Tiv orthography. Journal of Igbo language and linguistics. 4\&5.137-144.

[15] Wurm, S. A. (2003). Threatened languages in the Western Pacific area from Taiwan including Papua New Guinea. Bad Godesberg, Germany: Arnold-Akademie. 


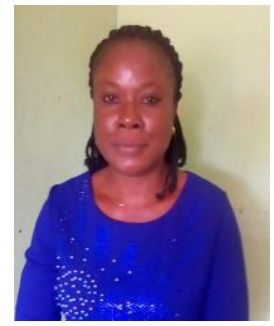

Juliana G. Mamah was born in Enugu Ezike, Enugu State on 10th August. She has Bachelor of Arts Degree and Master of Arts Degree in Linguistics at the University of Nigeria, Nsukka. Juliana specialises in Psycholinguistics. She has co-published "Slang usage amongst students in urban areas: An insight of Warri metropolis. Igbo scholars International Journal of Igbo Scholars Forum, Nigeria, 13(1), 37-56. Mrs. Mamah is a member of Linguistic Association of Nigeria.

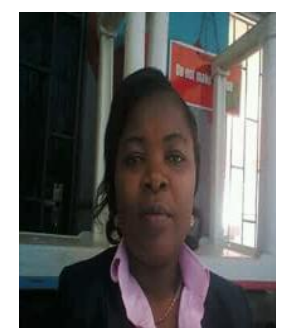

Jacinta U. Eze was born in Ovoko, Enugu State on 30th July. She has Bachelor of Arts Degree and Master of Arts Degree in Linguistics at the University of Nigeria, Nsukka. Jacinta specialises in Sociolinguistics and Discourse Analysis. She has co-published "Slang usage amongst students in urban areas: An insight of Warri metropolis. Igbo scholars International Journal of Igbo Scholars Forum, Nigeria, 13(1), 37-56. Mrs. Eze is a member of Linguistic Association of Nigeria.

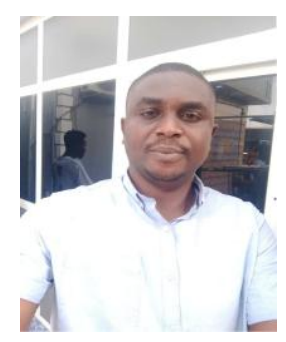

Bestman E. Odeh was born in Lagos, Nigeria on 7th June. He hailed from Abraka, Delta state, Nigeria. He had his Bachelors of arts degree and Master of arts degree from the University of Nigeria, Nsukka. He specialises in Morphology and syntax. He has published some articles including: Pluralisation strategies in the Urhobo language, _Ogbazuluobodo Journal_ 1(1) 283-293, lexical ambiguity in Urhobo, _journal of linguistics association of Nigeria_, \& Linguistic anthropological approach to Urhobo anthroponyms, _Ikenga International journal of Institute of African studies,_ 21(1\&2) 66-77 etc. Mr Bestman is a member of the Linguistic association of Nigeria (JOLAN).

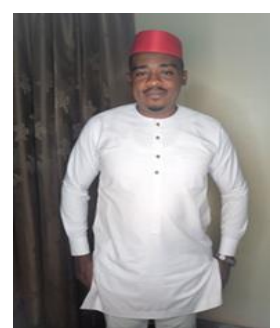

Ifeanyi J. Nwosu was born in Enugu, Enugu State of Anambra on 15th of March. He has a Bachelor of Arts Degree and Master of Arts Degree in Linguistics at the Nnamdi Azikiwe University, Awka. Ifeanyi specializes in Morphology, Semantics and Sociolinguistics. He has published some articles including: Nominalisation in Igbo anthroponyms: The case of Agentive and Gerundive nominal derivatives, IDEAL International Journal of Igbo scholars Forum, Nigeria, 12(2) Dec. 2019, 75-95, and Sociocultural Significance of Igbo Personal Names with Negative Markers, IDEAL International Journal of Igbo scholars Forum, Nigeria, 12(2) Dec. 2019, 111- 132. Mr. Ifeanyi is a member of Linguistics Association of Nigeria and Igbo Scholars Forum of Nigeria. 